\title{
PRODUCTION, ECONOMIC GROWTH AND CONFLICT IN RISKY ELECTIONS
}

\author{
Kjell Hausken and Mthuli Ncube
}

Kjell Hausken is a Professor in the Faculty of Social Sciences at the

University of Stavanger, Norway

email: kjell.hausken@uis.no

Mthuli Ncube is a Professor of Public Policy at the Blavatnik School of Government and Fellow of St Anthony's College, University of Oxford

email: mthuli.ncube@bsg.ox.ac.uk

\begin{abstract}
This paper analyses typical situations which exist before and after an election. First, the incumbent and his or her challenger make choices that affect the election results. Second, the election itself determines who wins. Third, the loser may or may not accept defeat. If the defeat is not accepted, either a standoff or a coalition between the incumbent and challenger follows. We assume that the incumbent directs his or her resources into the following activities, which affect the chance of winning an election: production, fighting with the challenger, and providing public goods. Similarly, the challenger directs his or her resources into production and fighting with the incumbent. We examine six possible election outcomes based on whether the incumbent wins, the challenger wins, and whether a standoff or coalition arises after either one of the players wins. We draw conclusions about the effect of the various choices which the incumbent and challenger make. Our analysis is mapped to and tested against empirical data from 51 African elections held between 2006 and 2011 (including one in Eritrea in 1993), which are classified into the six outcomes. A variety of regression results are determined. For example, the current empirical material shows that the election outcome depends crucially on fighting between the incumbent and challenger, and less on public goods provision to the population.
\end{abstract}

Keywords: election, fighting, production, risk, game, conflict. 
Acknowledgement: We thank Finn Tarp and Zuzana Brixiova for their useful comments, and are grateful to Kate Ryan, Siliadin Yaovi Gassesse and Letsara Nirina for their assistance.

\section{INTRODUCTION}

This paper models the pre- and post-election processes between an incumbent and a challenger. Linking the situations before and after an election is essential, because before an election the players make choices that will affect the election outcome. Similarly, after the election, the players face various consequences depending on who wins - and on how the winner and loser each react to the election results. Historically, incumbents have often failed to fully acknowledge the link that exists before and after an election. They also tend to over-estimate their ability to manage the adverse consequences of an election.

Before an election, the incumbent typically chooses between the following three avenues: production (to ensure economic growth); fighting with the challenger to remain in power, with such fighting either including or excluding actual violence; and providing public goods to appease the population. The results of the election will depend largely on how the incumbent makes these choices, and how the challenger chooses between fighting and production. After the election, the incumbent may accept the election result, or a coalition or standoff may ensue. These potential election scenarios affect the choices which the players make before an election. However, extremely few studies have analysed such pre- and post-election linkages.

Ellman and Wantchekon (2000) examine situations where a single strong party controls sources of political unrest. Such a party is likely to win if asymmetric information exists about the party's ability to cause unrest. ${ }^{1}$ The cost to citizens of violent elections is high, and may include loss of life, physical and mental injury, suppression of free speech, and human rights violations. Lindberg (2006) argues that democratising nations learn to become democratic through repeatedly behaving in a democratic manner, even if their elections tend to be flawed. Collier (2009) shows that the election process is meant to strengthen democratic institutions, but could in fact worsen conflict. Acemoglu and Robinson (2006) argue that the strength of democratic institutions does seem to have colonial origins, and that violent elections and post-election reactions may similarly have a colonial

1 See, for example, the studies by Alesina (1988), Alesina and Rosenthal (1995), and Calvert (1985). Schmitter (1978), Schedler (2007), Ashworth and De Mesquita (2008) and others have similarly analysed flawed elections, typically those which are held by autocrats and involve violence and manipulation. 
legacy. Gandhi and Przeworski (2009) and Fearon (2011) analyse government decisions to comply with an electoral outcome.

Our study focuses on Africa, which has been slow to establish democratic institutions and has experienced reversals of democratic processes. Election outcomes in most African countries have been challenged as being not free and fair. Some elections have been violent, followed by more violence after the election. Even democracies which are considered well-established, such as Kenya, have experienced some violence during the electoral process. Among sub-Saharan African countries, elections have established democracy in certain countries but caused reversals in others. The model which we used as the basis for our study is also relevant beyond Africa. For example, the fall or transformation of autocracies in North Africa and the Middle East has so far caused unsteady transitions to democracy after various revolutions in 2011 and 2012. Similarly, the fall of communism in the late 1980s paved the way for democratic election of new leaders.

Between 2006 and 2011 there were 50 African elections, plus one held in Eritrea in 1993, making a total of 51 relatively recent elections. ${ }^{2}$ In 34 of these 51 elections the incumbent won, compared with 17 in which the challenger won. Of the 34 wins, 21 were uncontested, 11 caused a standoff, and 2 resulted in a coalition. Of the 17 losses, in 11 the incumbent conceded defeat, there were no (0) standoffs, and 6 resulted in a coalition. In terms of the effect of an election on the real economy, the GDP growth rates before and after each election are unclear. Fosu (2008) found that indexes of electoral competitiveness are U-shaped in terms of GDP growth.

Election disputes are more common in Africa than on other continents. As shown in Table 2 later in this paper, some African coalitions stand out. Kenya, Zimbabwe and the Ivory Coast were characterised by violent elections and more violence after the election, with the incumbent spending resources on fighting, production, and public goods provision. In the 2007 Kenya elections, the incumbent did not win outright but won 102 out of 210 parliamentary seats. The close election results meant that both parties claimed victory and the right to form a new government; these competing claims resulted in violence. Some leadership individuals in both parties were later named by the International Criminal Court (ICC) as having instituted such violence. However, after the violent dispute, the two parties came together to form a coalition government.

The 2008 Zimbabwe election was similar. A stand-off between the two leading candidates should determine the winner, but in this case the opposition party

2 Libya (no elections during this period) and Swaziland (no political parties) were excluded from this study. 
refrained from competing due to fear. A coalition government was negotiated. The 2010 Ivory Coast election was more extreme. Despite a seemingly professional preelection, after the actual election the losing incumbent refused to cede his power. An armed civil conflict ensued and was resolved partly by military intervention.

These contests of power have economic consequences. In Zimbabwe, the economy grew at minus $5 \%$ on average over an 8 -year period during the political standoff (2000 to 2008). The incumbent, realising he had a lot to lose, compromised and co-opted the challenger into a government of national unity; this resulted in a degree of economic recovery and shifted the effort from fighting to production. The economy recovered after this political resolution, and grew at roughly $8 \%$ annually between 2009 and 2011. However, further effort was needed to keep the coalition going. In 2011, the incumbent broke the coalition because he discovered new natural resources and received rent for these. This increased his appetite and resources for fighting so as to keep the rent.

The Ivory Coast economy also experienced a sharp drop in GDP growth due to a political standoff. In 2011 the Ivory Coast experienced an external agent of restraint, namely the United States and the international community, which refused the coalition and cooption option. These external agents tried to force the incumbent to leave power.

For the above three countries and indeed in many others, one situation was evident before the election and a new situation arose after the election. In addition, political institutions can affect the choices made by an incumbent and his or her challenger. For example, one expects parliamentary systems to provide greater incentives than presidential systems for coalition formation (Cheibub 2007; Diermeier 2006; Laver and Shepsle 1990; Strom 1984). Electoral rules can also have an impact (Cox 1997; Persson \& Tabellini 2003).

\section{THE MODEL}

As already mentioned, before an election both the incumbent and a challenger have to make choices. These choices include whether to focus on production to ensure economic growth, and / or to fight with the opponent, and / or to provide public goods to the population. After the election, it is determined whether the incumbent or challenger wins. The two possibilities are shown in Table 1 below, in the second column from the left. Thereafter the loser must decide whether or not to accept defeat; this is shown as four possibilities in the third column of Table 1. The six final possible election outcomes are shown in the right column, where 'W' stands for 'incumbent wins' and 'L' stands for 'incumbent loses'. 
Table 1

Situations pre- and post-election, and six outcomes

(WP, WS, WC, LP, LS, LC).

\begin{tabular}{|c|c|c|c|}
\hline $\begin{array}{l}\text { Before } \\
\text { election }\end{array}$ & $\begin{array}{l}\text { After election } \\
\text { result is known }\end{array}$ & $\begin{array}{l}\text { After } \\
\text { incumbent } \\
\text { and challenger } \\
\text { have assessed } \\
\text { the election } \\
\text { result }\end{array}$ & Final outcome \\
\hline \multirow{6}{*}{$\begin{array}{l}\text { The incum- } \\
\text { bent and } \\
\text { challenger } \\
\text { make choices }\end{array}$} & \multirow[t]{3}{*}{ Incumbent wins } & $\begin{array}{l}\text { Challenger } \\
\text { accepts defeat }\end{array}$ & $\begin{array}{l}\text { Incumbent remains in power: } \\
\text { Outcome WP }\end{array}$ \\
\hline & & \multirow{2}{*}{$\begin{array}{l}\text { Challenger } \\
\text { does not accept } \\
\text { defeat }\end{array}$} & Standoff: Outcome WS \\
\hline & & & Coalition: Outcome WC \\
\hline & \multirow[t]{3}{*}{ Incumbent loses } & \multirow{2}{*}{$\begin{array}{l}\text { Incumbent } \\
\text { does not accept } \\
\text { defeat }\end{array}$} & Coalition: Outcome LC \\
\hline & & & Standoff: Outcome LS \\
\hline & & $\begin{array}{l}\text { Incumbent } \\
\text { accepts defeat }\end{array}$ & $\begin{array}{l}\text { Challenger becomes new incumbent: } \\
\text { Outcome LP }\end{array}$ \\
\hline
\end{tabular}

If the election loser accepts defeat, the result is an orderly process. The outcome is described as WP if the incumbent remains in power (top right cell of Table 1), and as LP if the challenger becomes the new incumbent and takes over power (bottom right cell of Table 1). If the election loser does not accept defeat, either a standoff or a coalition occurs. This gives four additional outcomes, as shown in the far right column of Table 1. If the challenger does not accept defeat, either a standoff (WS) or a coalition (WC) occurs. Similarly, if a losing incumbent does not accept defeat, either a standoff (LS) or a coalition (LC) occurs.

We assume that both the incumbent and the challenger have resources that can be directed or converted towards various purposes. Fighting with a challenger can take the form of violence, intimidation, persuasion, bribery, lobbying, fraud and so on. Providing public goods means providing security, education, health care, and other services which the population expects or hopes to get. Similarly, the challenger can direct resources into production or fighting with the incumbent. However, because the challenger is not in power, we assume that he or she cannot provide public goods for the population.

The incumbent and challenger have to strike a delicate balance in directing their resources. These choices will determine who wins the election. One 
unrealistic benchmark is that the incumbent and challenger do not fight. In this scenario, the incumbent directs the bulk of his or her resources into generating public goods and the remaining resources into production, which should mean that the incumbent wins the election and stays in power. By contrast, if the incumbent directs ample resources into production but directs limited resources into public goods and into fighting with the challenger, the incumbent can expect to lose the election. Because the challenger is likely to fight with the incumbent in the hope of gaining power, the incumbent has little choice but to match this fight. However, the incumbent must also provide public goods to prevent the population from turning against him or her. Yet if the incumbent directs all resources to fighting and public goods provision, no resources will be available for production. This would mean that economic growth is impossible, which is detrimental for the country.

In other words, the odds of the incumbent winning the election increase when the incumbent spends more on fighting and public goods provision. However, limits exist to the incumbent's fighting and public goods provision, since without production everyone loses. Similarly, the odds of the incumbent winning the election decrease when the challenger's fighting increases. Once again, however, limits exist to the challenger's fighting, since without production everyone loses.

\section{EMPIRICAL MAPPING OF OUTCOMES}

Table 2 below shows the results for 51 African elections between 2006 and 2011. The 1993 election in Eritrea is included. Libya is excluded as there were no elections during this period, and Swaziland is also excluded as its elections do not involve any political parties.

The table shows the election date, the winner (I for incumbent and C for challenger), the outcome (six possible outcomes), whether the dispute was violent, the population size, the GDP, and whether the press is free. We label the incumbent's fighting as $F_{i^{\prime}}$ the incumbent's public goods provision as $G$, and the challenger's fighting as $\mathrm{F}_{c}$. These three variables each have four possible values: $\mathrm{h}$ for high, $\mathrm{m}$ for medium, 1 for low, and 0 for none. The column titled ' $\mathrm{W}$ ' shows whether the incumbent (I) or challenger (C) won the election. The column titled 'outcome' refers back to Table 1, and shows which of the six possible outcomes applied.

Of the 51 elections which we studied, the incumbent won 34 and the challenger won 17 . Of the 34 wins, 21 were uncontested, 11 resulted in a standoff, and 2 resulted in a coalition. Of the 17 losses, in 11 outcomes the incumbent conceded defeat, there were 0 standoffs, and 6 resulted in a coalition. 


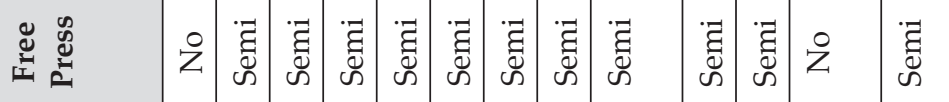

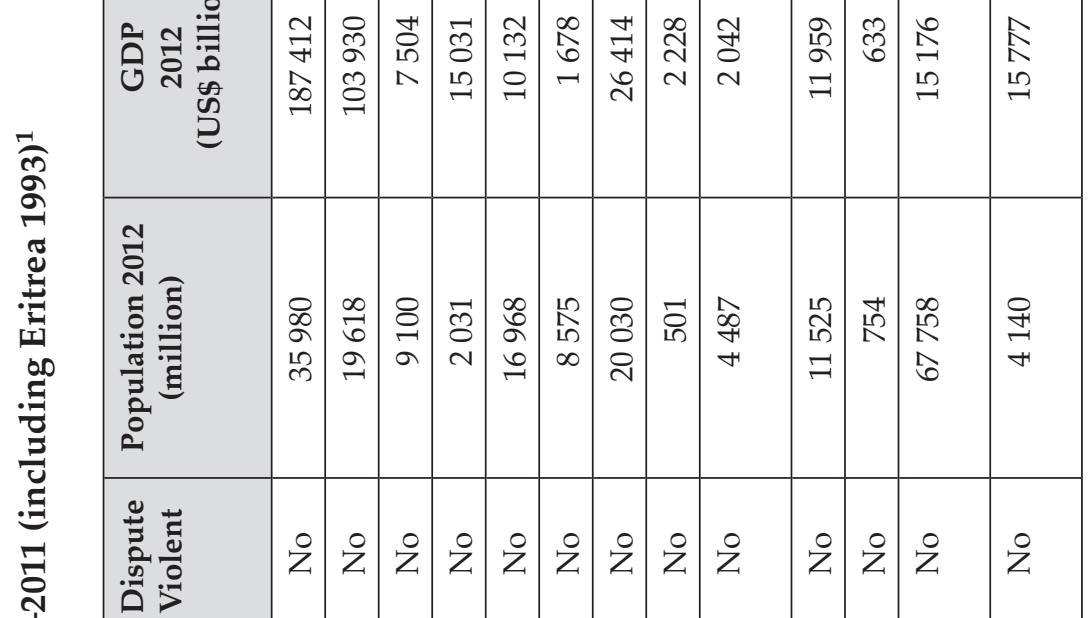

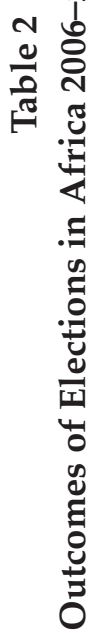

\begin{tabular}{|c|c|c|c|c|c|c|c|c|c|c|c|c|c|}
\hline 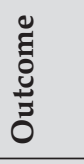 & $\frac{1}{3}$ & $\frac{5}{3}$ & $\frac{1}{3}$ & $\frac{5}{3}$ & $\frac{5}{3}$ & 3 & 3 & $\frac{1}{3}$ & $3^{\infty}$ & $\sum^{\infty}$ & $a_{a}$ & $\frac{1}{3}$ & $i_{3}^{\infty}$ \\
\hline 3 & - & $\neg$ & $\neg$ & $\neg$ & $\neg$ & $\neg$ & - & $\neg$ & $\neg$ & - & $\cup$ & • & $\neg$ \\
\hline II $^{\circ}$ & દ & $\Xi$ & દ & દ & દ & घ & $\Xi$ & દ & ع & ع & 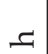 & $\Xi$ & ᄃ \\
\hline$\cup$ & ᄃ & $工$ & 工 & ᄃ & ᄃ & 工 & $\simeq$ & 工 & - & દ & $\Xi$ & 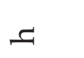 & - \\
\hline$\Psi^{-7}$ & ᄃ & $工$ & ᄃ & ᄃ & ᄃ & 工 & $\simeq$ & 工 & ઘ & $\Xi$ & - & ᄃ & घ \\
\hline 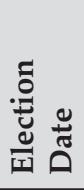 & $\frac{\frac{8}{8}}{\frac{d}{a}}$ & 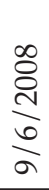 & $\frac{\vec{\sigma}}{\frac{\vec{N}}{m}}$ & 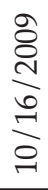 & 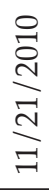 & 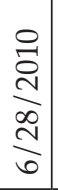 & 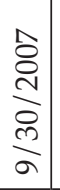 & 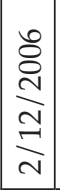 & $\frac{\vec{\sigma}}{\stackrel{\vec{N}}{a}}$ & 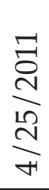 & 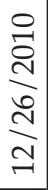 & 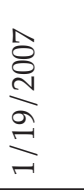 & 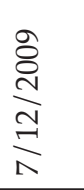 \\
\hline$\vec{E}$ & 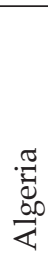 & 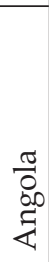 & • & 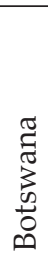 & 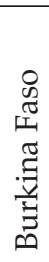 & 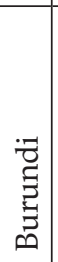 & 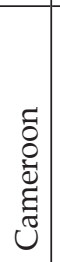 & $\begin{array}{c}\frac{0}{0} \\
\stackrel{0}{0} \\
\stackrel{0}{0} \\
\stackrel{0}{U}\end{array}$ & 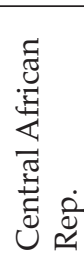 & $\frac{\widetilde{\Xi}}{\mathcal{U}}$ & $\begin{array}{l}0 \\
0 \\
0 \\
\Xi \\
0 \\
0\end{array}$ & 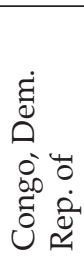 & 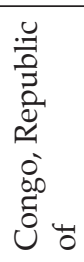 \\
\hline$\stackrel{\circ}{Z}$ & - & $N$ & $n$ & H & in & 0 & $\Lambda$ & $\infty$ & $a$ & $\stackrel{\circ}{-1}$ & $\exists$ & $\stackrel{\sim}{\sim}$ & $\stackrel{M}{\longrightarrow}$ \\
\hline
\end{tabular}

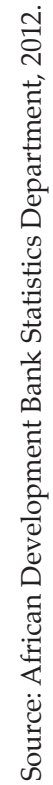




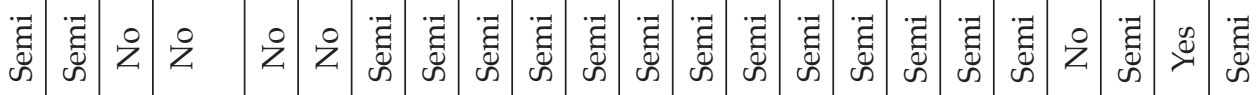

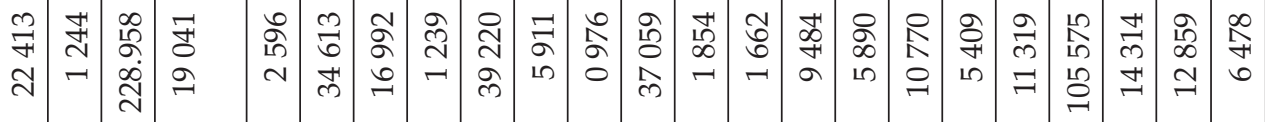

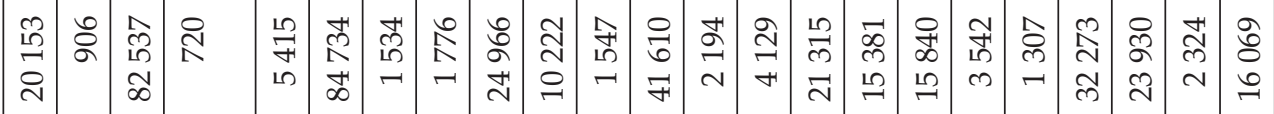

:

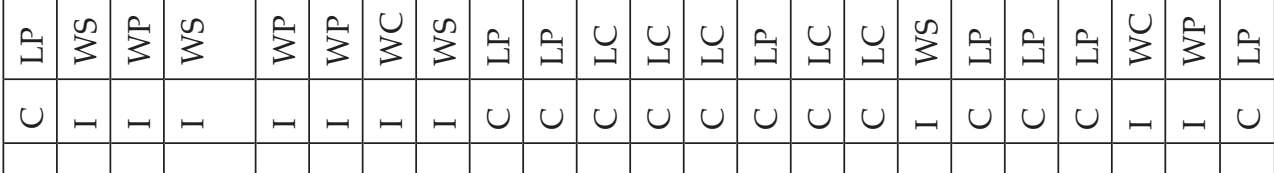

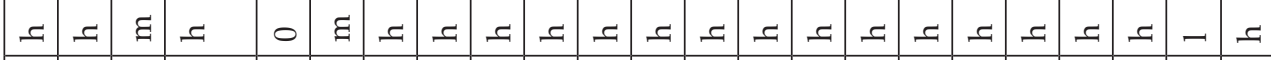

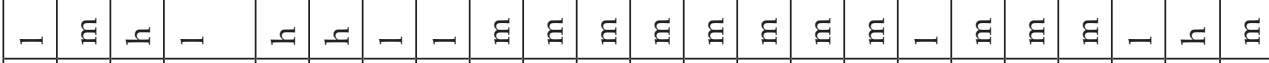

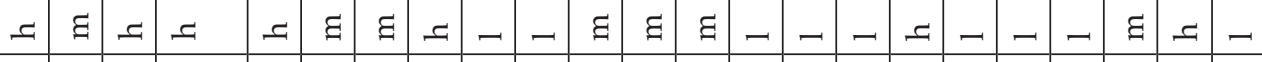

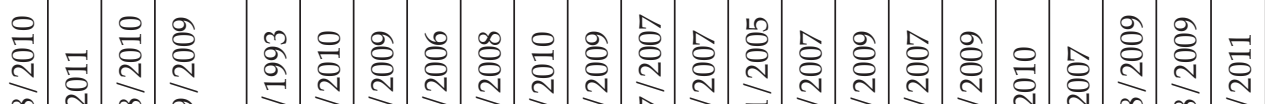

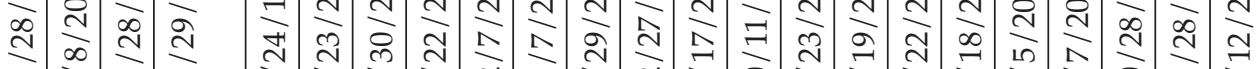

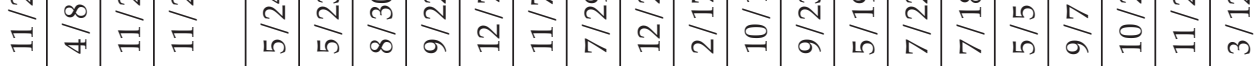

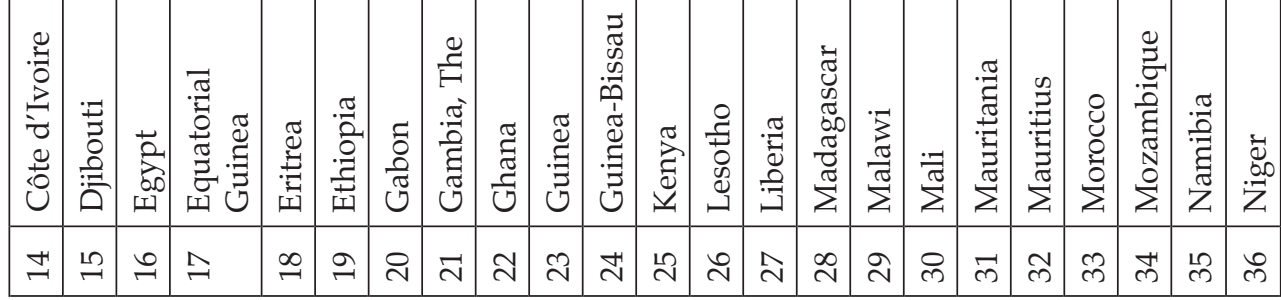




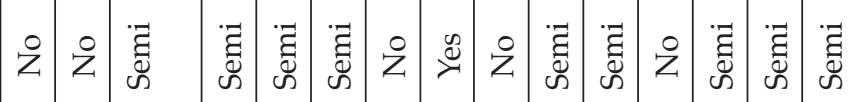

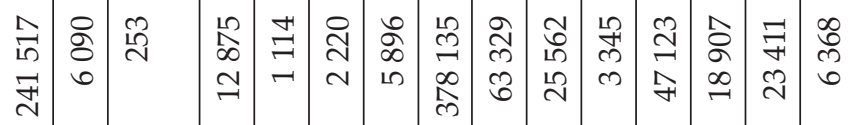

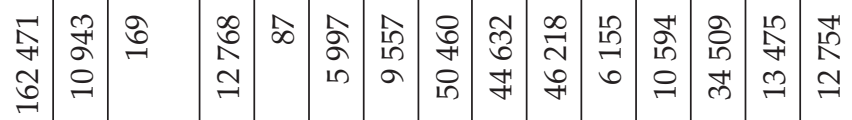

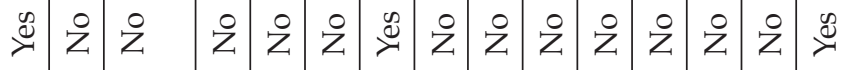

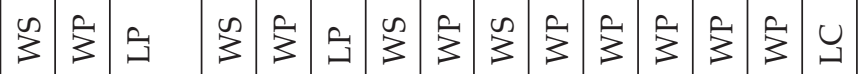

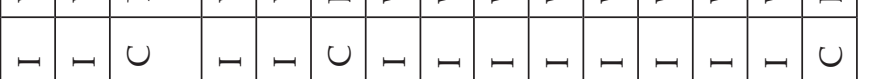

×

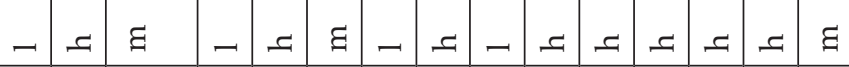

a 2 a

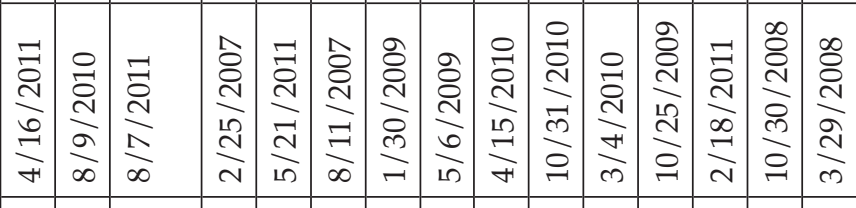

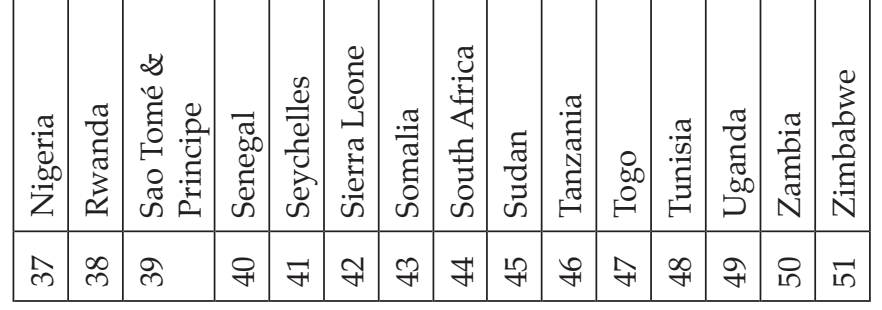

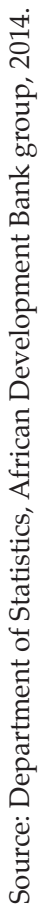


A good starting point for empirical determination is Table 2, which is based on history. From this empirical data we attempted to establish trends. One may then proceed to collect or estimate data about election results and related characteristics, using the historical trends to try and predict which of the six outcomes (WP, WS, WC, LP, LS, LC) is likely for a specific election. From Table 2 one can therefore glean insight to predict future election outcomes.

In terms of the six possible outcomes, the most frequent outcome is an outright win for the incumbent (21 wins, unchallenged). A standoff (S) is the second most likely outcome, regardless of whether an incumbent either wins (W) or loses (L). A coalition (C) is the third most likely outcome, again regardless of whether the incumbent wins or loses. The least likely outcome is that the challenger becomes the new incumbent (outcome LP).

We now analyse in more detail the 36 events in which the incumbent won. First, for 22 countries, the incumbent remained in power (WP). This often meant that the incumbent won with a clear margin or was otherwise able to suppress the challenger. Second, for 11 countries, a standoff (S) followed. Although the incumbent won, the margin was lower. The challenger challenged the incumbent, who refused to back down. The standoff could be costly. Third, for Gabon, Mozambique and Madagascar, a coalition (C) was formed. Again the margin by which the incumbent won was low, but the circumstances were such that a coalition was formed rather than a costly standoff.

We now consider the 15 events in which the incumbent lost. First, for 11 countries where the challenger became the new incumbent, the incumbent usually lost with a clear margin. Often public goods had not been provided, and fighting with the challenger was unsuccessful. Second, in four countries where a coalition was formed, the incumbent had generally lost with a less clear margin. In such cases, circumstances often prompted the incumbent to challenge the results fiercely. Third, no countries in this group experienced a standoff.

\section{TESTING THE MODEL EMPIRICALLY}

Identifying all parameters and variables in the scenarios of interest to this study was empirically challenging. We therefore chose to use three independent variables in the analysis, namely the incumbent's fighting $\left(\mathrm{F}_{\mathrm{i}}\right)$ and public goods provision $(\mathrm{G})$, and the challenger's fighting $\left(\mathrm{F}_{\mathrm{c}}\right)$. The three independent variables each had four possible values: zero (0), low (1), medium (m) and high (h). The dependent variable was the final election outcome, which had six possible codes: WP, WS, WC, LP, LS and LC. 


\section{All possible outcomes}

From Table 2, we constructed a $6 \times 51$ matrix. The rows showed the African countries, and the columns contained the election outcomes (WP, WS, WC, LP, LS, LC). The abbreviations for the election outcomes have been explained earlier in this paper and the information is not repeated here. For each country, only one of the six outcomes was possible, and that outcome was assigned a dummy code of 1 . The remaining five outcomes (which had not occurred) were assigned 0 for that country. For example, if WP had occurred it was assigned 1, whereas WS, WC, LP, LS, LC were all assigned 0. One of the authors (Mthuli Ncube) used the available data from the African Development Bank and rated the fighting variables $\mathrm{F}_{\mathrm{i}}$ and $\mathrm{F}_{\mathrm{c}}$ according to his own expert judgment. The ratings were assigned on an ordinal scale (i.e. rank-ordered) from 0 to 3 according to the intensity of fighting. The same author rated the public goods provision (variable $\mathrm{G}$ ) ordinally from 0 to 3 , according to the degree of public goods provision.

Table 3 below shows the results of the correlation analysis, using a Spearman rank correlation, which is appropriate for categorical and ranked data. The analysis showed that a positive and statistically significant relation exists between a higher level of $F_{i}$ and the incumbent's chances of staying in power (WP). The corollary is that higher $F_{i}$ is associated with a lower chance of the challenger taking power. Similarly, higher $\mathrm{F}_{\mathrm{c}}$ increases the challenger's chance of either winning or of forming a coalition with a victorious incumbent. However, although higher $F_{i}$ raises the incumbent's chance of winning, it also lowers the odds of a successful coalition if the challenger does not accept the incumbent's victory.

Table 3

Correlation coefficient (Spearman rho) between election outcome and $F_{i^{\prime}} G$ and $F_{c}$

\begin{tabular}{|l|c|c|c|c|c|c|}
\hline Independent variables & \multicolumn{5}{|c|}{ Election outcome (dependent variable) } \\
\hline & WP & WS & WC & LP & LS & LC \\
\hline Incumbent's fighting effort $\left(\mathrm{F}_{\mathrm{i}}\right)$ & $0.684^{* *}$ & -0.120 & -0.009 & $-0.683^{* *}$ & - & -0.120 \\
\hline Public goods provision $(\mathrm{G})$ & $0.705^{* *}$ & -0.216 & $-0.549^{* *}$ & -0.241 & - & -0.068 \\
\hline Challenger's fighting effort $\left(\mathrm{F}_{\mathrm{c}}\right)$ & $-0.902^{* *}$ & 0.137 & $0.421^{* *}$ & $0.573^{* *}$ & - & 0.137 \\
\hline
\end{tabular}

Note: Asterisks $\left.{ }^{(*}\right)$ indicate statistical significance the $1 \%$ level. 


\section{Scenario 1: The incumbent wins}

Table 4 below shows the findings of our analysis of elections where the incumbent won $(n=34)$. First, a high level of fighting $F_{i}$ by the incumbent is quite strongly related to the incumbent's success $(\rho=0.56, p<0.01)$. Second, fighting $F_{c}$ by the challenger shows a strong inverse relationship with the incumbent's success $(\rho=-0.77, p<0.01)$, and is positively correlated with an eventual standoff $(\rho=0.67$, $\mathrm{p}<0.01)$. However, $\mathrm{F}_{\mathrm{c}}$ is not associated with the formation of a coalition. Third, a high level of public goods provision $G$ by the incumbent shows a massive positive correlation with the incumbent's success and the challenger accepting defeat $(\rho=0.97, p<0.01)$. Similarly, G shows a strong inverse relationship with a standoff; that is, the higher the level of goods provision by the incumbent, the lower the chances of an eventual standoff $(\rho=-0.8321, p<0.01)$. Also, $G$ is slightly related to the development of a coalition $(\rho=-0.3499, p<0.05)$. Table 4 was based on our $3 \times 51$ matrix, with African countries shown in rows and the election outcomes (WP, WS, WC) shown in columns.

Table 4

Incumbent wins: rank correlation between election outcome and $F_{i^{\prime}} G$ and $F$

\begin{tabular}{|l|c|c|c|}
\hline Independent variables & \multicolumn{3}{|c|}{ Election outcomes } \\
\hline & WP & WS & WC \\
\hline Incumbent's fighting effort $\left(\mathrm{F}_{\mathrm{i}}\right)$ & $0.5623^{* * *}$ & $-0.3575^{* *}$ & $-0.4507^{* * *}$ \\
\hline Public goods provision $(\mathrm{G})$ & $0.9705^{* * *}$ & $-0.8321^{* * *}$ & $-0.3499^{* *}$ \\
\hline Challenger's fighting effort $\left(\mathrm{F}_{\mathrm{c}}\right)$ & $-0.7646^{* * *}$ & $0.6721^{* * *}$ & 0.2430 \\
\hline
\end{tabular}

Note: Asterisks indicate statistical significance at the $\left.5 \%{ }^{(* *}\right)$ and $1 \%\left(^{(* *}\right)$ levels.

\section{Scenario 2: The challenger wins}

Table 5 shows the findings of our analysis of elections where the incumbent lost $(n=17)$. The strongest two correlations both involved $F_{i}$ and each had a magnitude of 0.39 (rounded). The incumbent's fighting $\mathrm{F}_{\mathrm{i}}$ showed a modest positive relationship with the challenger's ability to assume power, and a modest negative relationship with the formation of a coalition. However, neither of these associations was statistically significant, and nor were any other correlations between the tested variables. It is possible that the relatively small sample size $(\mathrm{n}=17)$ affected this result, which should therefore be interpreted with caution. Table 5 was again based on our $3 \times 51$ matrix. 
Table 5

Challenger wins: rank correlation between election outcomes and $F_{i^{\prime}} G$ and $F$

\begin{tabular}{|l|c|c|c|}
\hline \multirow{2}{*}{ Independent variables } & \multicolumn{3}{|c|}{ Election outcomes } \\
\hline & LP & LS & LC \\
\hline Incumbent's fighting effort $\left(\mathrm{F}_{\mathrm{i}}\right)$ & $-0,3849$ & - & 0,3849 \\
\hline Public goods provision $(\mathrm{G})$ & $-0,1846$ & - & 0,1846 \\
\hline Challenger's fighting effort $\left(\mathrm{F}_{\mathrm{c}}\right)$ & - & - & - \\
\hline
\end{tabular}

\section{Regression analysis}

In the empirical analysis so far, we tested for the strength of the correlation between the election outcome and each of the variables individually. Next we test for all of them together. We are particularly interested in understanding the relative importance of fighting by the incumbent and challenger in determining the election outcome. For example, does the provision of public goods matter as an election-winning strategy, compared with intensified fighting?

We assigned the values $6,5,4,3,2,1$ to the six outcomes WP, WS, WC, LP, LS, LC respectively. We also assigned the dummy codes $0,1,2,3$ to 0,1 (low), $\mathrm{m}$ (medium) and $\mathrm{h}$ (high) respectively, as shown in Table 2 . We then performed categorical regression analysis of the election outcomes on $F_{i^{\prime}} G$ and $F_{c}$. The categorical regression method is appropriate for this study, given that we are utilizing categorical and qualitative data. The equation to be tested is

$$
Y=a+b_{1} F_{i^{\prime}}+b_{2} G+b_{3} F_{c}+u_{i}
$$

where $\mathrm{Y}$ denotes the election outcome, $a$ is constant, $b_{1}$ is the coefficient for $\mathrm{F}_{\mathrm{i}^{\prime}} b_{2}$ is the coefficient for $\mathrm{G}, b_{3}$ is the coefficient for $\mathrm{F}_{\mathrm{c}^{\prime}}$ and $u_{\mathrm{i}}$ is an error term. The results are shown in Table 6.

The results in Table 6 show that the regression coefficient between the degree of fighting by the incumbent and the election outcome is positive ( 0.07 , rounded). This suggests that as an incumbent increases his or her effort to fight for power, he or she is more likely to win and retain that power. However, the result was statistically not significant and the coefficient was very small, which means that no firm conclusions can be drawn and further studies are needed to clarify this finding. The only statistically significant result was for the degree of fighting by the challenger (significant at $1 \%$ ). This coefficient was large (0.986) and had 
a negative sign, which implies that a higher level of fighting by the challenger greatly increases the chance of defeating the incumbent and attaining power.

Table 6

Drivers of election outcomes: coefficient, F-value and significance as calculated by categorical regression

\begin{tabular}{|c|c|c|c|}
\hline Variable & Coefficient & F-value & Significance \\
\hline $\mathrm{F}_{\mathrm{i}}$ & 0.066 & 0.245 & 0.623 \\
\hline $\mathrm{G}$ & -0.125 & 0.492 & 0.690 \\
\hline $\mathrm{F}_{\mathrm{c}}$ & -0.986 & 71.855 & $0.000^{\text {** }}$ \\
\hline
\end{tabular}

$R$-Squared is 0.923 ; adjusted $R$-squared is $\left.0.913 ;{ }^{* *}\right)$ means significant at $1 \%$

One clear conclusion that can be drawn is that by comparing the coefficients, we note that increased fighting by the challenger is more likely to result in victory than is increased fighting by the incumbent. The coefficient for the provision of public goods was negatively related to the election outcome but was not statistically significant. Thus, the presence of fighting by the incumbent and challenger are more important variables.

\section{CONCLUSION}

In this study we analysed the choices which an incumbent and his or her challenger make before and after an election. Our analysis accounted for six election outcomes. Before an election, the incumbent and challenger make choices about whether to produce, fight, or provide public goods. With regard to election outcomes, postelection the winner is first determined, and thereafter it is determined whether the election loser accepts defeat. If the election loser refuses to be defeated, a standoff or coalition ensues. The various combinations of these factors give six possible election outcomes, which we analysed and the results of which are presented in this paper.

We assume that the incumbent invests his or her resources into production to ensure economic growth, into public goods to appease the population, and into fighting to oppose the challenger. The challenger invests his or her resources into production and fighting with the challenger. The incumbent's chance of winning an election increases when he or she provides public goods to appease the population and fights successfully with the challenger; however, resources 
must also be directed to production to ensure the country's economic growth. The incumbent has to strike a delicate balance between these opposing concerns.

Considering 51 countries, the model we used helped us to evaluate countries that try to seek legitimacy by holding fraudulent elections while providing some level of public goods. We analysed the variables 'fighting' and 'public goods provision' according to the three outcomes that may arise if the incumbent loses an election.

The relationship between the choices of the incumbent and challenger on the one hand, and the six post-election outcomes on the other hand, was tested by Spearman rank correlational analysis. Although the data was ordinal rather than numerical, the results showed certain distinct trends. First, a positive and statistically significant relationship was found between the incumbent's fighting effort and his or her chances of staying in power. Second, the challenger's fighting effort similarly increased his or her chances of winning the election, or of reaching a coalition if the incumbent won. Third, a higher fighting effort by the incumbent lowered his or her chances of obtaining a coalition if the challenger did not accept the incumbent's victory. The fourth finding was complex: if an incumbent won the election, a higher level of pre-election spending (by the incumbent) on public goods provision was associated with a better chance of winning the election. Such spending was also associated with a greater chance that the challenger would accept defeat. Similarly, it decreased the chances of a standoff or coalition.

The regression results showed that as an incumbent fights harder to retain power, he or she is indeed more likely to win an election. Similarly, as a challenger intensifies his or her fighting, he or she is also more likely to win against the incumbent. However, increased fighting by the incumbent is more likely to result in victory than is increased fighting by a challenger.

Our analysis also showed that based on the available data, fighting (by either the incumbent or challenger) is more important than the provision of public goods in determining an election outcome. The implication of this finding seems to be that politicians should focus solely on fighting rather than on the provision of public goods if they want to win elections. This is how politicians have won elections in Africa so far. However, the global environment is becoming increasingly democratised, and we do not expect this approach to be publicly acceptable for much longer.

Future research could focus on the decision by an autocratic regime to hold an election in the first place. In addition, an econometric analysis could be extended to include other countries. Furthermore, research could focus on analysing the incidence of revolutions in countries where public goods are provided for the benefit of a select few, and where the voice of citizens and the accountability of those in power are suppressed. 


\section{- REFERENCES}

Acemoglu, D \& Robinson, JA 2006, Economic origins of dictatorship and democracy. Cambridge University Press, Cambridge.

Alesina, A 1988, 'Credibility and policy convergence in a two-party system with rational votes', American Economic Review, vol. 78, pp. 796-806.

Alesina, A \& Rosenthal, H 1995, Partisan politics, divided government and the economy, Cambridge University Press, New York.

Ashworth, S \& De Mesquita, EB 2008, 'Electoral selection, strategic challenger entry, and the incumbency advantage', The Journal of Politics, vol. 70, no. 4, pp. 1006-1025.

Calvert, R 1985, 'Robustness of the multidimensional voting model: candidate motivations, uncertainty, and convergence', American Journal of Political Science, vol. 29, no. 1, pp. 69-95.

Cheibub, JA 2007, Presidentialism, parliamentarism, and democracy, Cambridge University Press.

Collier, P 2009, Wars, guns and votes, Harper, New York.

Cox, GW 1997, Making votes count, Cambridge University Press.

Diermeier, D 2006, 'Coalition government', in The Oxford handbook of political economy, (ed.) BW Weingast and DA Wittman, Oxford University Press, Oxford.

Ellman, M \& Wantchekon, L 2000, 'Electoral competition under the threat of political unrest', Quarterly Journal of Economics, vol. 115, no. 2, pp. 499-531.

Fearon, JD 2011, 'Self-enforcing democracy', The Quarterly Journal of Economics, vol. 126, pp. 1661-1708.

Fosu, AK 2008, 'Democracy and growth in Africa: Implications of increasing electoral competitiveness', Economics Letters, vol. 100, no. 3, pp. 442-444.

Gandhi, J \& Przeworski, A 2009, 'Holding onto power by any means? The origins of competitive elections', working paper, available at http:/ / citeseerx.ist. psu.edu / viewdoc/ download?doi=10.1.1.397.926\&rep=rep1\&type=pdf or https: / / scholar.google.com/ citations?view_op=view_citation\&hl=en\&user= L2Moqg8AAAAJ\&citation_for_view=L2Moqg8AAAAJ:W7OEmFMy1HYC

Laver, M \& Shepsle, KA 1990, 'Coalitions and cabinet government', American Political Science Review, vol. 84, no. 3, pp. 873-890.

Lindberg, SI 2006, Democracy and elections in Africa, John Hopkins University Press, Baltimore.

Persson, T \& Tabellini, G 2003, The economic effect of constitutions, MIT Press.

Schedler, A 2007, 'The Mexican standoff: the mobilization on distrust', Journal of Democracy, vol. 18, no. 1, pp. 88-102.

Schmitter, PC 1978, Elections without choice, MacMillan, London.

Strom, K1984, 'Minority governments in parliamentary democracies: The rationality of nonwinning cabinet solutions', Comparative Political Studies, vol. 17, no. 2, pp. 199-227. 